\title{
Hypothyroidism in Childhood and Adolescence
}

\author{
Deise Dutra Terra Carvalho1, Denise Rosso Tenório Wanderley Rocha1, \\ Alberto Krayyem Arbex ${ }^{1,2}$ \\ ${ }^{1}$ Division of Endocrinology, IPEMED Medical School, São Paulo, Brazil \\ ${ }^{2}$ Visiting Scientist, Harvard T. H. Chan School of Public Health, Harvard University, Boston, USA \\ Email: deisedtc@uol.com.br
}

Received 13 December 2015; accepted 18 January 2016; published 21 January 2016

Copyright (C) 2016 by authors and Scientific Research Publishing Inc.

This work is licensed under the Creative Commons Attribution International License (CC BY). http://creativecommons.org/licenses/by/4.0/

(c) (i) Open Access

\begin{abstract}
Juvenile hypothyroidism is an unfrequent form of hypothyroidism that affects children. If not diagnosed and treated properly, it may cause severe neurological disorders during growth. The most frequent difficulties are found in school performance, difficulties in concentration, hyperactivity or fatigue and damage on the onset of puberty. Starting levothyroxine as a drug of choice is essential, and it should be made according to the age and weight of the child. Laboratory tests for control should be requested periodically, along with a strict control of the child's development and growth. The family-doctor relationship, along with a clear guidance on the importance of treatment, is critical to achieve a successful treatment. This article is a review about the main clinical features of hypothyroidism in childhood, especially in developing countries, providing key aspects of adherence and characteristics of its follow-up.
\end{abstract}

\section{Keywords}

Thyroid Gland, Neonatal Screening, Hypothyroidism, Congenital Hypothyroidism, Juvenile Hypothyroidism, Levothyroxine

\section{Introduction}

It has been increasingly common to diagnose and to treat hypothyroidism in adults [1]. However, several studies show the relevance of the thyroid gland during the fetal life and the first two years of life, defining that gland is essential for child growth and development [2] [3]. To understand the pathophysiology of the thyroid gland and how it should be addressed during childhood and adolescence, a prior knowledge of metabolic pathways of thyroid hormones is necessary, along with their important role in the body [4]. Besides acting on the physical and 
neurological development, it also operates in the regulation of body temperature and in a series of biochemical processes, making it essential for the perfect functioning of all organs of our body [5].

A specific approach towards children should be made judiciously since birth. A good evaluation of the newborn starts, together with neonatal screening, better known as "heel prick test", which aims to identify chronic diseases, such as congenital hypothyroidism [6]-[8].

Family is essential at this moment, because the newborn depends on his/her parents for the screening test and childcare follow-up to be done. Health professionals are engaged on the orientation of populations, especially in poor and underdeveloped countries as Brazil, India and where health care is unsufficient. Health workers need to identify, diagnose and treat chronic diseases in early childhood. Doctors must be aware of the signs and symptoms of the most common chronic diseases in childhood, in order to learn how to address this unfrequent though important diagnosis, minimizing injuries or consequences to the child and to the family.

\section{Diagnosis and Treatment}

\subsection{Laboratory Diagnosis}

Signs and symptoms of congenital hypothyroidism in the newborn are subtle [6]. An early diagnosis of the disease is only possible, in most cases, through newborn screening, dosing thyroid stimulating horm, one (TSH) levels in blood samples collected on filter paper, followed by measurement of thyroxine (total $\mathrm{T}_{4}$ ) in serum sample, obtained from the heel, as shown in Figure 1 [7]-[10].

TSH is the most sensitive screening test for establishing the diagnosis of primary hypothyroidism [11]. TSH dosage is also a useful tool to guide the replacement dose of thyroid hormone, except in patients with secondary hypothyroidism. In these patients free $\mathrm{T}_{4}$ is the best method to be used. Adequate replacement of thyroid hormone results in normalization of serum TSH. Thyroxine is present in the serum in the free form (free $\mathrm{T}_{4}$ ) and connected to TBG (total $\mathrm{T}_{4}$ ) [12].

Assays for total $\mathrm{T}_{4}$ measure it in both states and are useful for establishing the diagnosis of hypothyroidism and assess response to treatment. The serum total $\mathrm{T}_{4}$ and free $\mathrm{T}_{4}$ are low in patients with primary hypothyroidism.

In the case of juvenile hypothyroidism is important to the check the presence of serum antithyroid antibodies that are useful only to establish the diagnosis of chronic lymphocytic thyroiditis or Hashimoto's thyroiditis [13], the most common cause of hypothyroidism and goiter in children [2] [14]. Titles antithyroglobulin thyroid anti-

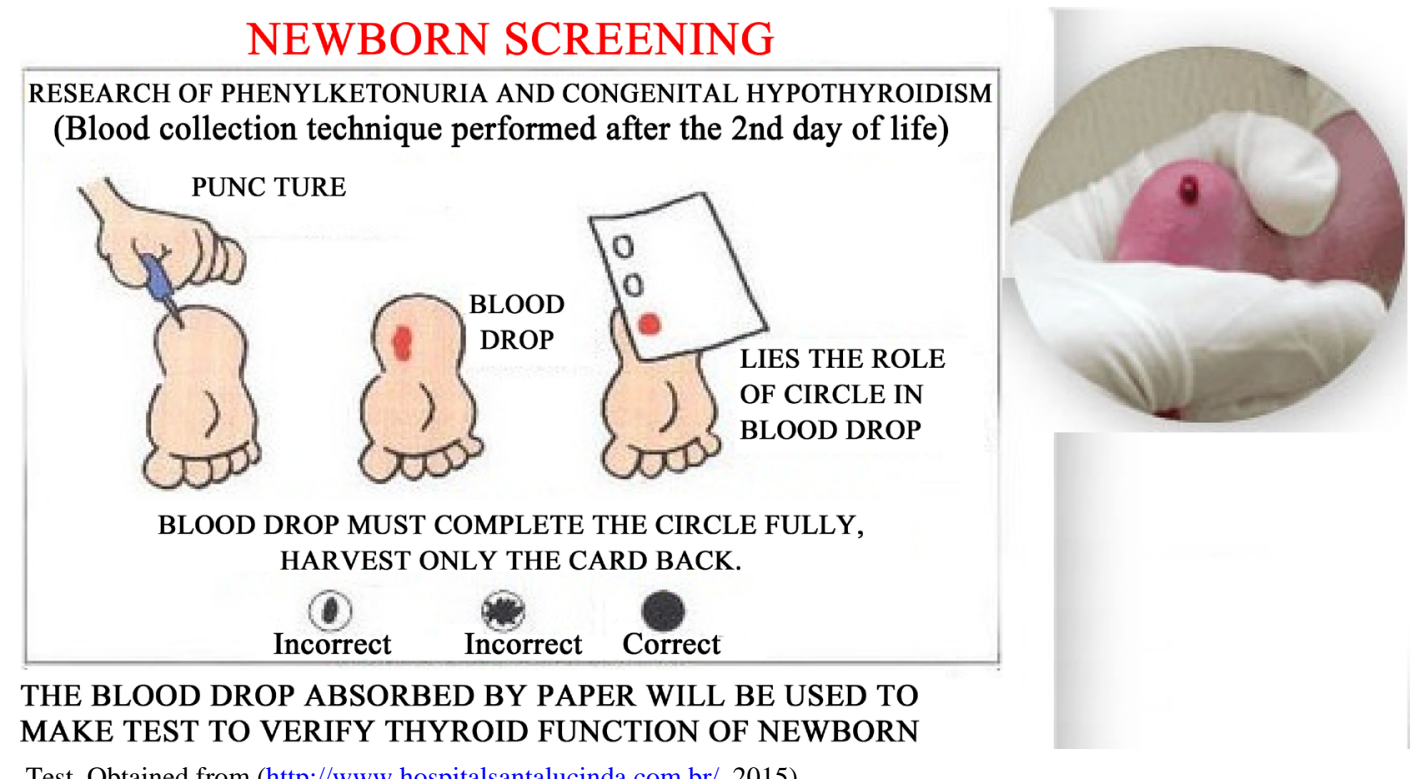

Test. Obtained from (http://www.hospitalsantalucinda.com.br/, 2015).

Figure 1. This image was used in a campaign done at the hospital Santa Lucinda, Sorocaba, Brazil. It describes to health care personnel how the blood sample should be performed. This procedure is standardized in Brazil. Unfortunately it is not performed in all Brazilian newborns, due to health disparities throughout the country. 
bodies (anti-Tg) and antiperoxidase (TPO) are present in 85\% to 90\% of children with Hashimoto's thyroiditis.

Children diagnosed with acquired hypothyroidism, having received appropriate treatment at least five years before the onset of puberty, often grow to reach adult final height consistent with their genetic potential [13] [15].

\subsection{Newborn Screening Results}

In Brazil, the Neonatal Screening Program uses the TSH cut-off value of $10 \mathrm{mIU} / \mathrm{L}$ (immunofluorimetric method). When the TSH values are above $20 \mathrm{mIU} / \mathrm{L}$, the newborn must undergo a medical check, where it will be examined and prompted a collection of blood for serum TSH and total $\mathrm{T}_{4}$ and/or free. When TSH levels are between $10 \mathrm{mIU} / \mathrm{L}$ and $20 \mathrm{mIU} / \mathrm{L}$, the newborn is called for a second test on filter paper [10].

Most patients, in this second test, show normal results and do not require further monitoring. On those with TSH levels below $10 \mathrm{mUI} / \mathrm{L}$, there is no need for a follow-up. TSH levels in unaffected children may be higher during the first 24 hours, due to the stress of labor, but usually normalize within 72 hours [9] [10].

Some programs suggest reducing the TSH cutoff for $5 \mathrm{mIU} / \mathrm{L}$ to $6 \mathrm{mIU} / \mathrm{L}$, as this would enable the diagnosis of some cases of Congenital Hypothyroidism undetected with $10 \mathrm{mUI} / \mathrm{L}$ limit, but some authors question the benefit of reducing this TSH limit, since there is no evidence of cognitive impairment in patients with TSH levels between $5 \mathrm{mIU} / \mathrm{L}$ and $10 \mathrm{mIU} / \mathrm{L}$, and moreover, this strategy may increase the number of false negatives, and with it the number of recalls and treated children diagnosis and all financial and emotional cost associated [14].

Despite the collection of newborn screening being performed by the 5th day of birth, the doctor only gets the results in the first query that occurs in the first month. It is important that the health unit, through the nurse, goes to the home of the newborn within the first seven days of life, to guide the family about all the symptoms related to chronic diseases screened in the test, and to remind of the importance of the introduction of vitamin $\mathrm{D}$, which should remain until the second year of life or according to the physician's discretion, assisting in the prevention of various diseases [13].

In the flow chart presented by Figure 2, there is a didactic and practical for clinical use, facilitating the cutting points and conducts in specific cases.

\subsection{Treatment}

The main purpose of treating congenital hypothyroidism is to keep the patient in an euthyroid clinical condition, providing thus normal growth, adequate psychomotor and pubertal development.

Treatment consists of daily oral administration of thyroid hormone in the morning. The standard substance used is sodium levothyroxine (sodium salt of synthetic isomer of thyroxine- $\mathrm{T}_{4}$ ), orally and fasting, for better absorption and efficacy of the medication. It has a half-life of seven days, favoring the administration once daily. Only seldom, when a clinical condition restrains oral use, it needs to be done by parenteral route (in this case, use is made with $75 \%$ to $80 \%$ of the recommended dose orally). Treatment should be started as early as possible, preferably before 13 days of life, to prevent clinical consequences of lack of thyroxine [16].

The dose varies depending on the age of the newborn and their body weight. Young children require higher doses than older children and adults. It should begin with doses of $10-15 \mathrm{mg} / \mathrm{kg} /$ day for the newborn to term, and the dose should be recalculated as the child's weight gain and $\mathrm{T}_{4}$ and TSH levels are observed in laboratory

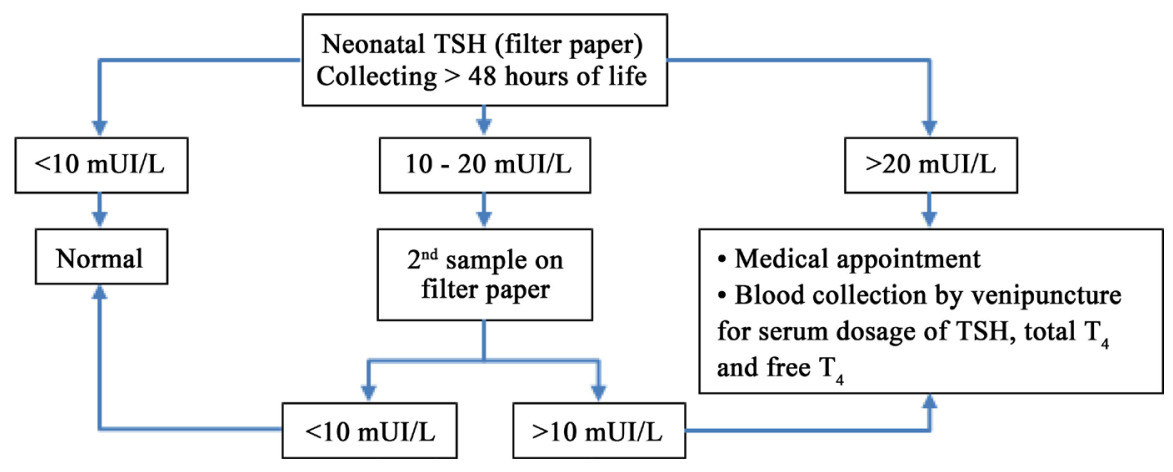

Figure 2. Flowchart of neonatal care. Brazilian ministry of health, screening. 
tests [17]. The first objective, taking high dose thyroxine levels, is to reach the upper normal range within 1 - 2 weeks.

Serum TSH concentration may not return promptly to normal levels, even when using high doses of thyroxine hormone due to the feedback system; however, after 2 years of age, the levels tend to normalize, and TSH becomes an adequate treatment goal. Ideally, the levels of free $\mathrm{T}_{4}$ during the first 10 year of life levels remain stable, preferably in the upper half of normality, as shown in Table 1.

It is important to confirm, always at each visit, adequate adherence to treatment. Guiding the family about the importance of regular treatment is essential. Warrant is needed if the children remain in a hypothyroid condition, because growth and development potentially will be adversely affected. It is not advised to fraction the drug tablet [18]. Currently there are the following commercial presentations of levothyroxine in the Brazilian market: $25 \mathrm{mcg}$, 38, 50, 75, 88, 100 112, 125, 150 and $200 \mathrm{mcg} / \mathrm{tablet}$.

An overdose of levothyroxine sodium is undesirable, and should be avoided not only because of the symptoms of thyrotoxicosis (irritability, insomnia, intense crying, tremors, sweating, loose stools and tachycardia) but also because of the possibility of promoting advancement of bone age, and because it increases the risk of premature closure of sutures the cranial (craniosynostosis), when higher doses are maintained for prolonged periods [19].

It is essential to individualize the dosage of levothyroxine for each patient, through a rigorous follow-up control, involving clinical monitoring that seeks to identify signs and symptoms suggestive of inadequate dosages.

In addition to the clinical evaluation, it is necessary to keep a hormonal control obtained through laboratory tests that provide a high level of confidence for the prescription dosage of the drug.

Other indicators of the effectiveness and treatment efficiency can be obtained with the control of physical growth and maturation, as well as the child's developmental level (Güell, 1998) [20].

\section{Compliance to Treatment}

Adherence to treatment is a complex behavioral process that requires the interaction of several factors, including the patient's comprehension and skills, the environment where the patient is inserted, his/her social support, health care system characteristics where the patient is doing the follow-up, the adequate operation of that system, evaluation and accessibility of resources in the health system, characteristics of the disease in question and its treatment [21].

The quality of the relationship between family and patient with his/her doctor is a key issue, and sometimes it is a determining factor for compliance to be achieved [22]. Treatment should be clarified to the patient and his family in a clear and simple way for appropriate follow-up to be achieved. When adjustments are needed, these should be thoroughly explained, in order not to generate doubts.

Some patients may have difficulty adhering to treatment in our country and throughout Latin America, especially because of low education levels and embarrassment in questioning the doctor [23].

Within the family, there may be differences between families where the medication is implemented, since many caregivers such as parents, grandparents and other relatives may assume the responsibility to provide the medication regularly to the child. Therefore, during the consultation, the doctor should be as friendly and attentive as possible, to detect those patients that, for many reasons, do not follow the correct instructions.

To avoid these misunderstandings, there are questionnaires that raise specific behaviors that describe the medical recommendations, and are used during the consultation, in order to know if the patient is following what was proposed. It is important to allow patients to expose their fears and doubts [24].

Table 1. Dosage of treatment of hypothyroidism by age group.

\begin{tabular}{cc}
\hline Age & Daily dose of levothyroxine (mcg/Kg/day) \\
\hline $\mathbf{0}$ - $\mathbf{6}$ months old & $10-15$ \\
$\mathbf{7}$ - $\mathbf{1 2}$ months old & $6-8$ \\
$\mathbf{1}$ - $\mathbf{5}$ years old & $5-6$ \\
$\mathbf{6}$ - $\mathbf{1 2}$ years old & $3-5$ \\
$>\mathbf{1 2}$ years old & $2-3$ \\
Adults & $1.6-1.7$ \\
\hline
\end{tabular}




\section{Conclusions}

The approach towards a child with a chronic illness requires professional support from birth and throughout life, so that the physician and caregivers may intervene in and prevent the occurrence of sequelae, and thus reduce the additional losses caused by the disease. Congenital hypothyroidism, as a chronic disease with a good prognosis when treated and followed properly, enables the prevention of mental retardation, and allows a normal development of children treated with thyroid hormone in the correct time.

The Acquired or Youth Hypothyroidism is further worried some, because parents seek help only when they receive complaints about delays in the development and school behavior, which may sometimes be confused with psychiatric or social disorders. Therefore, an inappropriate treatment could be done, without treating the correct cause of the disorders [25].

Information is essential for the family of such patients. They should be provided during the clinical approach, the time of childcare or during routine clinical visits. The family must be able to understand which damages could affect their children, if not diagnosed and treated properly. The affected child will depend directly on the caregiver to provide the medication, reach compliance and request the hormone dosage control tests.

\section{Acknowledgements}

The authors would like to thank IPEMED Brazil for supporting continuous research towards a better medical education in Brazil and abroad.

\section{References}

[1] Nogueira, C.R., Kimura, E.T., Carvalho, G.A., Sgarbi, J.A., Ward, L.S., Maciel, L.M.Z., Silva, M.R.D., et.al. (2011) Projeto diretrizes clinicas na saúde suplementar-tratamento do hipotireoidismo.

[2] Burton, B.K. (1998) Inborn Error of Metabolism in Infancy: A Guide to Diagnosis. Pediatrics, 102 , E69. http://dx.doi.org/10.1542/peds.102.6.e69

[3] Clarke, J.T.R. (2002) A Clinical Guide to Inherited Metabolic Diseases. Cambridge University Press, Cambridge.

[4] Fonseca-Alaniz, M.H., Takada, J., Alonso-Vale, M.I.C. and Lima, F.B. (2007) Adipose Tissue as an Endocrine Organ: From Theory to Practice. Jornal de Pediatria, 83, S192-S203.

[5] Derksen-Lubsen, G. and Verkerk, P.H. (1996) Neuropsychologic Development in Early Treated Congenital Hypothyroidism: Analysis of Literature Data. Pediatric Research, 39, 561-566. http://dx.doi.org/10.1203/00006450-199603000-00028

[6] Oerbeck, B., Sundet, K., Kase, B.F. and Heyerdahl, S. (2003) Congenital Hypothyroidism: Influence of Disease Severity and L-Thyroxine Treatment on Intellectual, Motor, and School-Associated Outcomes in Young Adults. Pediatrics, 112, 923-930. http://dx.doi.org/10.1542/peds.112.4.923

[7] American Academy of Pediatrics (1993) Newborn Screening for Congenital Hypothyroidism: Recommended Guidelines. Pediatrics, 91, 1203.

Hackshaw, A.K. and Wald, N.J. (2000) Screening for Congenital Hypothyroidism. Journal of Medical Screening, 7, 212. http://dx.doi.org/10.1136/jms.7.4.212

[8] Secretaria de Assistência à Saúde: Coordenação de Atenção Especializada, Ministério da Saúde, Brasil (2004) Manual de Normas Técnicas e Rotinas Operacionais do Programa Nacional de Triagem Neonatal. Editora MS, 3, 91.

[9] Ministério da Saúde, Brasil (2001) Portaria GM/MS no. 822/GM, de 06 de junho de 2001. Dispõe sobre a instituição do Programa Nacional de Triagem Neonatal, no âmbito do Sistema Único de Saúde de vários distúrbios metabólicos, incluindo doenças falciformes e outras hemoglobinopatias, Brasília.

[10] Fonseca, A. and Braga, C. (2008) Manual de Rotinas em Triagem Neonatal. Rubio, São Paulo, 128. Santana, J.C.B., Sapiro, A., Kipper, J.D., et al. (2011) Saúde da criança e do adolescente-Puericultura na prática pediátricaPorto Alegre-editora. Editora PUCRS.

[11] Dillon, R.S. (1983) Distúrbios da Tireoide. In: Manual de Endocrinologia: Diagnóstico e tratamento das doenças endócinas e metabólicas, Ed. Guanabara Koogan, Rio de Janeiro, Brazil, 549.

[12] Medeiros Neto, G.A. (2002) Fisiologia da glândula tireoide no período fetal, na infância e na adolescência. In: Setian, N., Ed., Endocrinologia pediátrica: Aspectos físicos e metabólicos do recém-nascido ao adolescente, Sarvier, São Paulo, 255-259.

Sutan-Assin, M. (1990) Developmental and Behavioral Disorders in Children with Congenital Hypothyroidism. Paediatrica Indonesiana, 30, 125-132. http://www.ncbi.nlm.nih.gov

[13] Bargagna, S. (1994) The Prevention of Disorders Due to Congenital Hypothyroidism: The Experience of a Neuropsy- 
chological Follow-Up. Annali dell' Istituto Superiore di Sanità, 30, 343-345. http://www.ncbi.nlm.nih.gov

[14] Chagas, A.J., Dias, V.M.A., Viana, M.F.S., Nunan Neto, B., Braga, M.L.E. and Medeiros Neto, G. (2004) Cartilha do Hipotireoidismo Congênito. Núcleo de Pesquisa em Apoio Diagnóstico da Faculddade de Medicina da UFMG.

[15] Chiesa, A., de Papendieck, L.G., Keselman, A., et al. (1998) Final Height in Long-Term Primary Hypothyroid Children. Journal of Pediatric Endocrinology and Metabolism, 11, 51-58. http://dx.doi.org/10.1515/jpem.1998.11.1.51

[16] Giusti, M.M.C. (2003) A iniciativa Pioneira da APAE em São Paulo. Em: Medeiros Neto, G., Ed., Hipotireoidismo congênito no Brasil, como era, como estamos, para ondevamos, Instituto da Tireoide, São Paulo, 1-12.

[17] Saad, M.J.A., Maciel, R.M.B. and Mendonça, B.B. (2007) Endocrinologia. (Tireóide: Fisiologia e avaliação diagnóstica). Atheneu Editora, São Paulo, 1251 p.

[18] Daniela, V.M.S., Nuvarte, S., Leonardo, P., et al. (2015) Arquivos Brasileiros de Endocrinologia \& Metabologiav. 46 n.2 São Paulo abr. 2002 Tireoidite de Hashimoto na Infância e na Adolescência: Estudo Retrospectivo de 43 Casos.

[19] Rivkees, S.A., Bode, H.H. and Crawford, J.D. (1988) Long-Term Growth in Juvenile Acquired Hypothyrodism: The Failure to Achieve Normal Adult Stature. The New England Journal of Medicine, 318, 599-602. http://dx.doi.org/10.1056/NEJM198803103181003

[20] WILLIANS tratado de endocrinologia 11 edição-editora elsevier.

[21] Güell, R. (1998) Enfermedades del Tiroides em niños y adolescentes. Permanyer Publications, Barcelona.

[22] Guyton, A.C. and Hall, J.E. (2002) Tratado de fisiologia médica. Guanabara Koogan, Rio de Janeiro, 803-812.

[23] William, W.H., Myron, J.L., Judith, M.S., et al. (2012) Current pediatria (Lange)-diagnóstico e tratamento-22 ediçãoed. Artmed.

[24] Mazzaferri, E.L. (1982) A Tireoide. In: Mazzaferri, E.L., Ed., Endocrinologia, Ed. Guanabara Koogan, Rio de Janeiro, 382.

[25] Ladenson, P.W., Singer, P.A., Ain, K.B., Bagchi, N., Bigos, S.T., Levy, E.G., et al. (2000) American Thyroid Association Guidelines for Detection of Thyroid Dysfunction. Archives of Internal Medicine, 160, 1573-1575. http://dx.doi.org/10.1001/archinte.160.11.1573 